\title{
Entanglement risk to western gray whales from commercial fisheries in the Russian Far East
}

\author{
Lloyd F. Lowry ${ }^{1, *}$, Vladimir N. Burkanov ${ }^{2}$, Alexey Altukhov ${ }^{2}$, David W. Weller ${ }^{3}$, \\ Randall R. Reeves ${ }^{4}$
}

${ }^{1}$ 73-4388 Paiaha Street, Kailua Kona, HI 96740, USA

${ }^{2}$ Kamchatka Branch of the Pacific Geographical Institute, Far East Branch of Russian Academy of Sciences, 6 Partizanskaya Street, Petropavlovsk-Kamchatsky 683000, Russia

${ }^{3}$ NOAA Fisheries, Southwest Fisheries Science Center, 8901 La Jolla Shores Drive, La Jolla, CA 92037, USA

${ }^{4}$ Okapi Wildlife Associates, 27 Chandler Lane, Hudson, Quebec J0P1H0, Canada

\begin{abstract}
Western gray whales Eschrichtius robustus (WGWs) are endangered, and their range overlaps areas where several important commercial fisheries operate in the Russian Far East (RFE). Throughout their range, gray whales commonly become entangled or entrapped in fishing gear. In the western North Pacific, they have been killed in set nets and seen entangled with ropes and float lines. Signs of fishery interactions on 28 of 150 living whales photographed near Sakhalin Island were reported in a published study. We describe characteristics of RFE fisheries that might entangle WGWs, including fishing effort based on daily catch reports from 2010-2014. We make a preliminary qualitative assessment of entanglement risk, taking into account factors including (1) evidence that the gear type has entangled large whales, (2) fishing effort, and (3) geographic and temporal overlap between WGWs and fishing activity. Fishing for salmonids with pelagic gillnets is no longer allowed in the RFE, and as long as the prohibition is being followed such fishing poses no risk to WGWs. In contrast, the coastal salmon set net fishery poses a high entanglement risk off northeastern Sakhalin and Kamchatka where WGWs feed very close to shore, and that situation should be mitigated. Bottom-set gillnet, demersal longline, snurrevad (also called Danish seine), and trap and pot fisheries overlap substantially with WGW distribution, and bycatch in those fisheries should at least be monitored. More rigorous risk assessment would require additional information on WGW distribution and movements.
\end{abstract}

KEY WORDS: Western gray whale - Eschrichtius robustus - Distribution - Russian Far East · Fisheries $\cdot$ Entanglement risk $\cdot$ Sakhalin Island

\section{INTRODUCTION}

Gray whales Eschrichtius robustus occur in the North Pacific Ocean and adjacent seas. An eastern stock ranges between Baja California and the Arctic Ocean. That stock is abundant and not assigned any special protective status (Carretta et al. 2015). The situation in the western North Pacific is more complicated. Historical evidence indicates that gray whales were resident in the western Pacific prior to modern commercial whaling, which began there in the 1890s and removed about 2000 animals during the 20th

\footnotetext{
*Corresponding author: llowry@hawaii.rr.com
}

century, mainly in Korean and Japanese waters (Kato \& Kasuya 2002, IWC 2015). Historically, many and possibly most of the gray whales in the western Pacific migrated along the Asian coast between eastern Russia and the South China Sea, judging by the location and timing of catches and other data (Weller et al. 2002, Reeves et al. 2008). However, sightings had become very infrequent by the middle of the 20th century, and there were suggestions that the western stock of gray whales (WGWs) was extinct (Bowen 1974), although this was rebutted (Brownell \& Chun 1977).

(C) The authors and, outside the USA, the US Government 2018. Open Access under Creative Commons by Attribution Licence. Use, distribution and reproduction are unrestricted. Authors and original publication must be credited.

Publisher: Inter-Research · www.int-res.com 
In recent decades, observations off northeastern Sakhalin Island and southern Kamchatka indicate that at least 200 gray whales now use those regions regularly during the summer and autumn feeding season, and numbers have been increasing steadily since the early 2000s (Western Gray Whale Advisory Panel [WGWAP]-17 report $^{\mathbf{1}}$ ). WGWs are listed as endangered in the Russian Red Data Book and under the US Endangered Species Act, considered depleted and strategic under the US Marine Mammal Protection Act, and are listed as Critically Endangered on the Red List of Threatened Species ${ }^{\mathrm{TM}}$ maintained by the International Union for Conservation of Nature (IUCN) (Reilly et al. 2008르). Although genetic studies have shown differences between the eastern and western populations (Lang et al. 2011), telemetric tagging (Mate et al. 2015) and photographic and genetic matching of individuals seen in both the eastern and western North Pacific (Weller et al. 2012) indicate that a proportion of the Sakhalin and Kamchatka animals migrate to coastal waters of western North America in the winter, where their distribution overlaps that of the eastern stock (see IWC 2015, 2016). In this paper, we refer to all gray whales that spend at least part of the year in the western Pacific south of $55^{\circ} \mathrm{N}$ latitude as WGWs (the gray whales that use waters of the Bering and Chukchi Seas during the summer/autumn feeding season are considered eastern gray whales).

Since 2002, two international bodies, the International Whaling Commission (IWC) Scientific Committee (SC) and the IUCN-led WGWAP, have been monitoring and evaluating reported instances of entanglement or entrapment (generally referred to as 'bycatch') of WGWs in fishing gear. At workshops and meetings, the SC recommended that WGW photographs be examined for evidence of disease, scars from killer whale Orcinus orca attacks, and human interactions (e.g. ship strikes and fishing gear entanglements and entrapments; IWC 2004); that an education campaign be conducted for fishermen and others throughout the potential range of WGWs, focused on documentation of stranded or bycaught whales and the need for efforts to release incidentally caught whales; and that all range states organize stranding networks and conduct aerial surveys and beach surveys for stranded or entangled gray whales (IWC 2006).

\footnotetext{
1All WGWAP meeting reports are available at https:// www.iucn.org/western-gray-whale-advisory-panel/panel/ meetings/glance-meeting-reports

2An updated assessment of 'Endangered' is scheduled for November 2018
}

The report of IUCN's Independent Scientific Review Panel (the predecessor of WGWAP) included a review of the evidence available at the time (20042005) concerning bycatch (including all forms of entanglement and entrapment) of WGWs in fisheries in east Asia, and fishery-caused mortality was cited among the factors contributing to cumulative effects on the population trajectory (Reeves et al. 2005). Subsequent observations of WGW entanglements (Weller et al. 2008, 2014, Kato et al. 2013, and see below) and recognition that additional mortality due to bycatch could cause the population to decline (IUCN 2009) led to a statement in a draft IWC/IUCN conservation management plan for WGWs that entrapment and entanglement in fishing gear was the greatest known threat (Brownell et al. 2010).

The present study had the following objectives:

- Describe and map the distribution and movements of WGWs in the Russian Far East (RFE)

- Collect and describe all available evidence of WGW entanglements in fishing gear throughout their range

- Describe and map the RFE fisheries that use gear that might catch gray whales

- Qualitatively assess the risks posed to WGWs from the fisheries in the RFE

- Suggest approaches for mitigating this risk.

\section{METHODS}

The authors of this paper have been directly involved in WGW studies and whale entanglement research and have participated in IWC and IUCNWGWAP meetings dealing with those topics. Relevant information provided at those meetings, and in associated papers and reports, was reviewed as part of this study. Additional information on the distribution and movements of WGWs in the RFE and on WGW entanglements in fishing gear was obtained from searches of published literature and direct contact with knowledgeable colleagues.

Commercial fisheries in the RFE use various types of gear and vessels, some of which can be hazardous to gray whales. Because very little information exists on WGW bycatch and interactions with fishing gear in the RFE, we used published information on large whale entanglements and entrapments elsewhere (Heyning \& Lewis 1990, Baird et al. 2002, Gilman et al. 2006, Artukhin et al. 2010, Song et al. 2010, Benjamins et al. 2012, Meÿer et al. 2011, Reeves et al. 2013, Werner et al. 2015) to identify fisheries that employ potentially dangerous gear types. These 
include fisheries that use long and loose ropes or cables for deployment of gear such as pots, hooks, and nets. We excluded trawl fisheries and most seine fisheries from our analysis because, by analogy with the more extensive data on gray whale entanglement in the eastern Pacific (Heyning \& Lewis 1990, Baird et al. 2002, IWC 2016) and given the complete absence of direct evidence of gray whale interactions with these types of fisheries in the western Pacific, we considered them of lower concern. We did, however, include the snurrevad (also called Danish seine) fishery. The snurrevad is a common gear type in the RFE that is used to catch demersal fish on the continental shelf, and there is evidence that large whales can become entangled in the gear. Other fisheries preliminarily identified as being of primary concern are coastal salmon set nets; drift gillnets set for salmon; bottom-set gillnets for demersal fish; all types of crab pots and traps, octopus pots, and whelk pots; and vertical longlines set for squid and bottomset longlines for demersal fish.

Our analysis covered several Food and Agricultural Organization (FAO) fishing areas in the RFE where WGWs are likely to occur (Fig. 1). We used a depersonalized daily catch report (DCR) dataset obtained from the Russian government-financed institution 'Centre of Fishery Monitoring and Communications' for 2010-2014. The Russian Federation requires that each fishing boat capable of fishing trips lasting over $24 \mathrm{~h}$ submit results of fishing activity electronically at the end of each day (i.e. a DCR). The DCR contains a unique boat identification code, the vessel's position (latitude and longitude) at the time the report is submitted, fishing gear code, number and total length of time of fishing operations that day, fish caught by species in metric tons including target and non-target species, and the code for the zone where fishing occurred. A total of 445431 DCRs exist in the $5 \mathrm{yr}$ dataset for all types of marine fisheries; this includes 312 types and modifications of fishing gear. In total, we selected and analyzed 238735 DCR records pertaining to the fisheries listed above and shown in Fig. 1 and Table 1. To map fishing effort, DCRs were assigned to $10 \mathrm{~km}$ grid cells and plotted. Maps were created using various tools of the R computing environment ( $\mathrm{R}$ Core Team 2016). Map layouts were generated using the 'maps' package (Becker et al. 2013) and the CIA World Data Bank II data (https://www.rdocumentation.org/packages/mapdata/ versions/2.3.0/topics/world2Hires). Bathymetry was

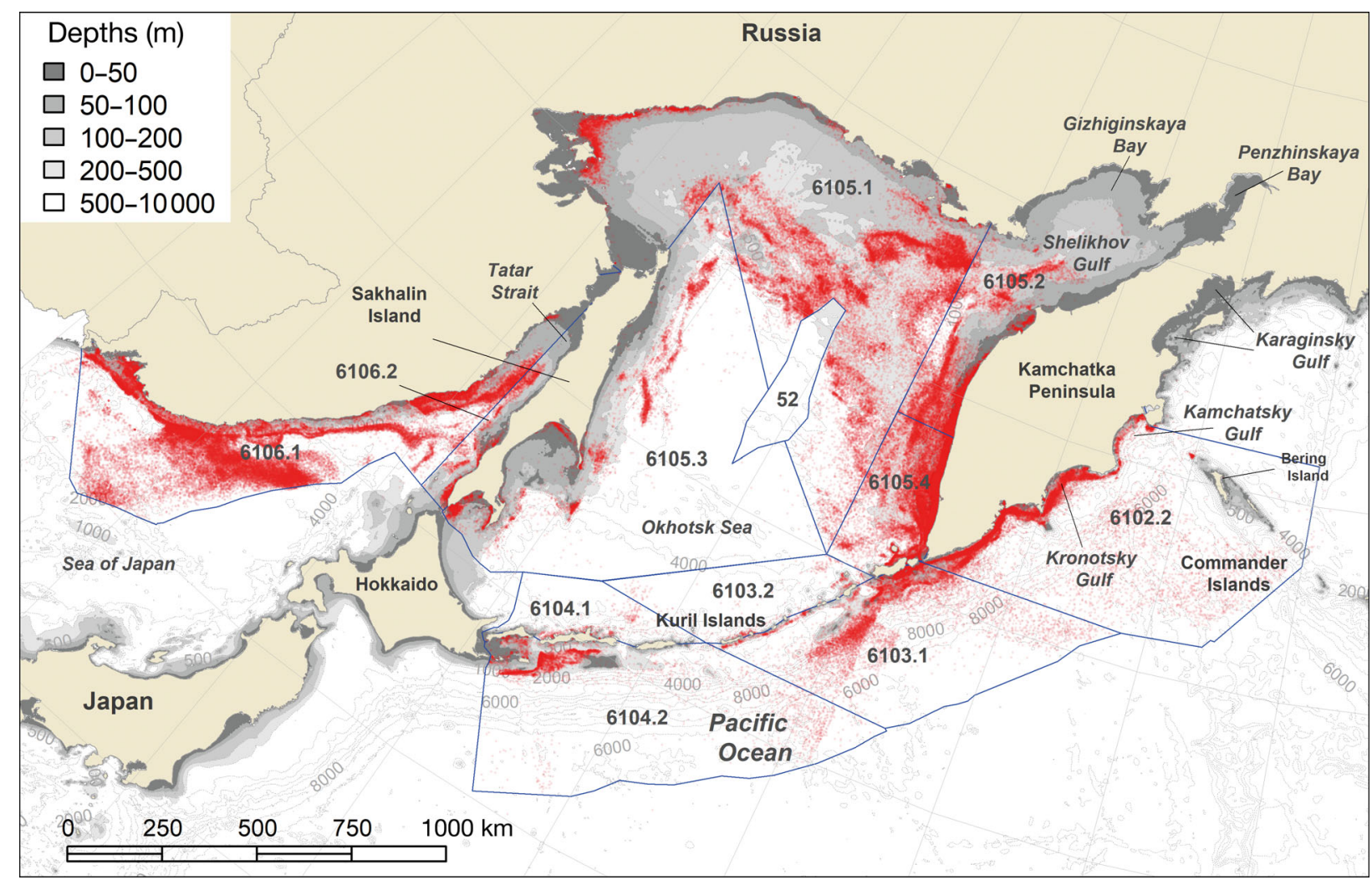

Fig. 1. FAO fishing zones (blue lines) and daily catch report locations (red dots) for selected fisheries for 2010-2014 that were used in analysis of potential interactions between western gray whales and Russian Far East fisheries 
Table 1. Fishing effort for selected marine fisheries in known or potential western gray whale habitat in the Russian Far East, 2010-2014

\begin{tabular}{|lcccccc|}
\hline \multirow{7}{*}{ Fishing gear types } & \multicolumn{7}{c}{ Number of vessel-days with catch $\left(\mathrm{yr}^{-1}\right)$} & \multirow{2}{*}{5 yr total } \\
& 2010 & 2011 & 2012 & 2013 & 2014 & \\
\hline Gillnets & & & & & & \\
Bottom-set & 1035 & 1025 & 1086 & 1112 & 916 & 5174 \\
Drift & 2544 & 2497 & 2797 & 2213 & 2335 & 12386 \\
Longlines & & & & & & \\
Demersal & 5862 & 6627 & 6730 & 6389 & 5648 & 31256 \\
Pelagic & 455 & 0 & 0 & 0 & 0 & 455 \\
Vertical & 3669 & 4946 & 5305 & 8356 & 7458 & 29734 \\
Snurrevad & 20656 & 18484 & 18034 & 15984 & 16477 & 89635 \\
Demersal traps & & & & & & \\
Crab cone & 10840 & 12657 & 11828 & 11095 & 9615 & 56035 \\
Crab (large) & 712 & 725 & 658 & 763 & 722 & 3580 \\
Demersal fish & 5 & 62 & 152 & 2 & 0 & 221 \\
Octopus & 583 & 433 & 554 & 317 & 332 & 2219 \\
Shrimp & 729 & 683 & 621 & 738 & 744 & 3515 \\
Whelk & 1328 & 968 & 825 & 839 & 565 & 4525 \\
Grand total & 48418 & 49107 & 48590 & 47808 & 44812 & 238735 \\
\hline
\end{tabular}

Sea in the latter half of the 19th century. Gray whales were observed consistently in the bays and gulfs of the far northeastern Okhotsk Sea from early May to the end of August and near Magadan along the north-central Okhotsk Sea coast from at least early June to early July and from midAugust to mid- or late September. American whalers apparently did not visit the coastal waters off northeastern Sakhalin Island where, since at least the 1980s, WGWs have assembled to feed throughout the summer and autumn.

Today, the northeastern Sakhalin shelf is the main feeding ground for WGWs in the RFE (Weller et al. 1999; see Fig. 2). This feeding ground is centered near the mouth of Piltun Lagoon and includes a nearshore and

generated using the General Bathymetric Chart of the Oceans data set with 30 s resolution (GEBCO 2014).

The coastal salmon set net fishery does not submit DCRs, so for it we used publicly available information on salmon fishing permits and rights, commercial salmon fishing regulations, quotas, and catches to assess potential effort. We also used information provided by Dmitry Lisitsyn and Nikolay Vorobiev (from Sakhalin Environment Watch [SEW], a local non-governmental organization in Yuzhno-Sakhalinsk) on actual locations where salmon set nets were fished at Sakhalin Island, derived from high-resolution satellite imagery. We included in our analysis only official commercial fishery effort information and did not include any illegal or non-commercial fishing effort for which no reliable information is available.

\section{RESULTS}

\section{Distribution and movements of WGWs in the RFE}

The historical distribution and abundance of gray whales in the Okhotsk Sea once greatly exceeded what is presently observed (Yablokov \& Bogoslovskaya 1984). European and American whalers operating in the western North Pacific (mainly in the Okhotsk Sea) took gray whales from the late 1840s to at least the mid-1880s (Henderson 1984, 1990). Reeves et al. (2008) plotted the approximate positions and dates (i.e. months) of 160 kills and sightings of gray whales by American whalers in the Okhotsk a nearby offshore feeding area (Demchenko et al. 2016). In a given year, approximately 100-150 whales use these areas. From 2002-2017 at Piltun, 131 individuals were documented to have used both nearshore and offshore areas either in the same year or over several years (Tyurneva et al. 2018). Mothers and calves use only the nearshore feeding area, especially the shallow waters very close to shore. In addition to the Piltun region, occasional sightings have been reported during the summer and fall in nearshore waters between Cape Elizabeth in northern Sakhalin and Vostochny Nature Reserve along the central east coast. In 2005, a summer sighting of several gray whales was reported in Severny Bay in northwestern Sakhalin (SEIC 2011).

Waters off southeastern Kamchatka, particularly Olga Bay, are apparently used at least occasionally for feeding by small numbers of gray whales (Vertyankin identified in coastal waters off southern and southeastern Kamchatka from 2004-2012, 85 were also photo-identified off Sakhalin (Tyurneva et al. 2018). In addition to southeastern Kamchatka, occasional summer sightings of gray whales have been reported along the east coast as far north as Karaginsky Gulf (Tyurneva et al. 2010). Gray whales have also been reported off southwestern to northwestern Kamchatka in the summer and autumn (Bradford et al. 2010).

There have been sporadic reports of gray whales off Kekurny Bay, Babushkin Bay, and Gizhiginskaya Bay in the northern Okhotsk Sea (SEIC 2011, Filatova et al. 2016) as well as off the Shantar Islands in et al. 2004). Of 161 gray whales individually photo- 
the far western Okhotsk Sea during the summer (Weller et al. 2013). In the past several decades, gray whales have been sighted occasionally off the northern Kuril Islands (Paramushir and Shiashkotan) in the eastern Okhotsk Sea, and near the Commander Islands (Medny and Bering) in the southwestern Bering Sea (Weller et al. 2013).

The majority of gray whale sightings in the RFE occur in coastal waters, often within $5 \mathrm{~km}$ of the shore, but non-calves are also seen regularly at locations such as the offshore feeding area near Piltun which is $20-45 \mathrm{~km}$ from the coast. Results from a recent satellite-tracking study in 2010-2011 showed 3 WGWs departing the Piltun feeding area in late November or early December and crossing open pelagic waters of the Okhotsk Sea as they moved eastward to the coast of southwestern Kamchatka (Mate et al. 2015). All 3 whales then made long migrations further eastward towards North America.

Fig. 2 shows a schematic of the known distribution and movements of gray whales in the RFE, based on recent and historical sightings, entanglements and strandings, and on satellite tracking of tagged individuals.

\section{Evidence of gray whale entanglement and entrapment in fishing gear}

Because they commonly feed near the bottom, often in nearshore areas, and generally use coastal migratory routes where fishing gear is concentrated, gray whales have a substantial risk of entanglement and entrapment.

\section{RFE}

Bycatch is not monitored systematically in many RFE fisheries, and data on whale entanglements and entrapments are therefore far from complete. Coastal regions are not systematically surveyed for beachcast animals, and carcasses are only detected and reported opportunistically. Those that are detected are rarely examined carefully for possible evidence of entanglement or other causes of death. Nonetheless, large whales (most of which were not identified to species but some of which could have been gray whales) are known to have been entangled in salmon driftnets in the RFE (Kornev 1994, Artukhin et al.

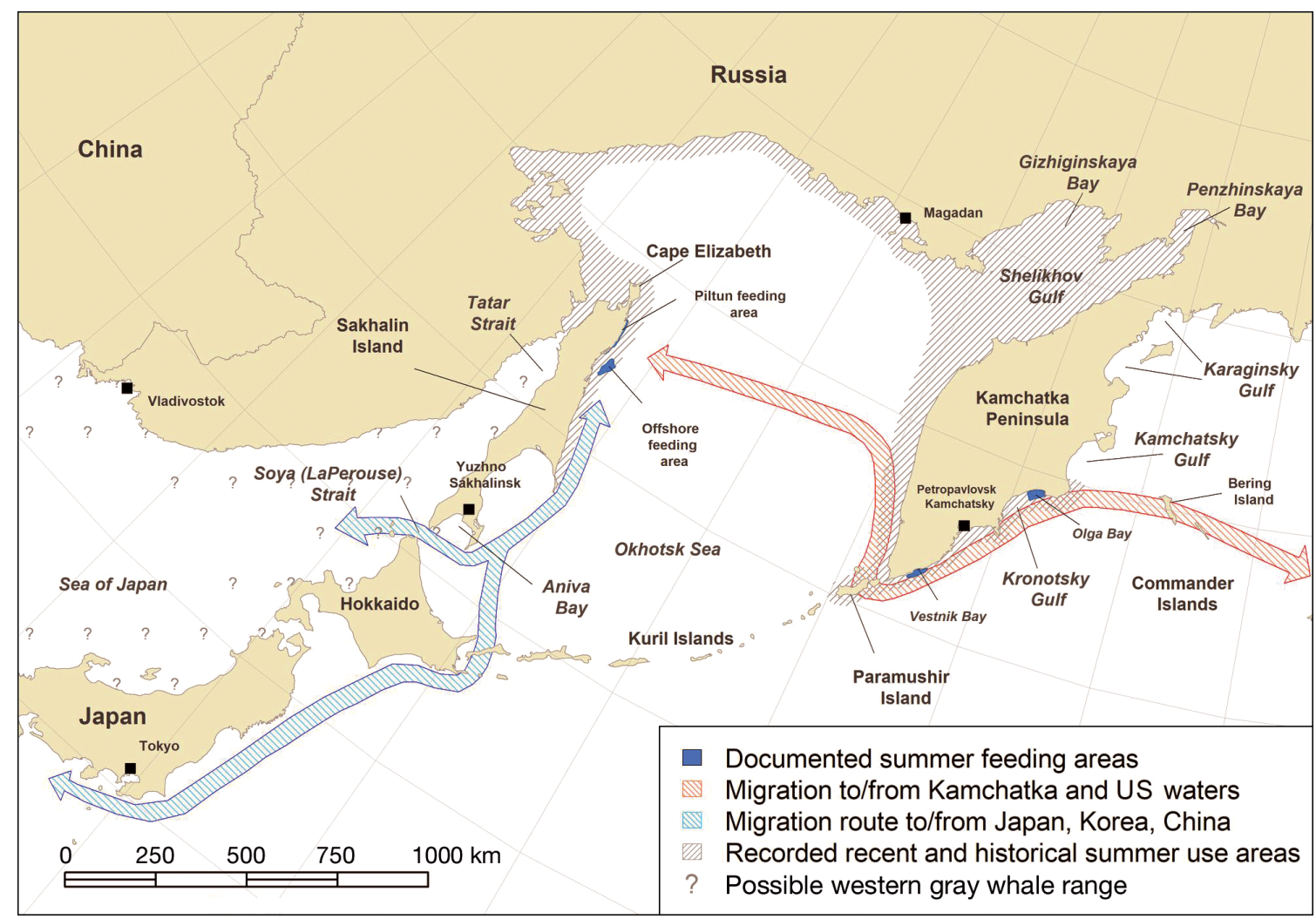

Fig. 2. Known and suspected distribution of western gray whales in the Russian Far East. Migration routes are not intended to represent narrow corridors with sharp edges but rather the general directions of migratory movements 
2010). During 1993-1999, when a large-scale Japanese salmon drift net fishery operating in the RFE was monitored by marine mammal observers every season, the estimated bycatch of large whales (most of them not identified to species) was 27-45 (Burkanov \& Nikulin 2001, Nikulin \& Burkanov 2001, Burkanov et al. 2007). Of those, 6-12 occurred on the Pacific side of the northern Kuril Islands. These estimates are minimums because there were numerous occasions when the net was not retrieved and the entangled object was not identified.

There is clear evidence of WGW-fishery interactions off eastern Sakhalin Island. In early September 2009, the stranded carcass of a $10 \mathrm{~m}$ male was examined by personnel from the Sakhalin Energy Investment Company (SEIC), a local veterinarian, and representatives of relevant authorities (Federal Supervisory Natural Resources Management Service [Rosprirodnadzor] and Federal Service for Veterinary and Phytosanitary Surveillance [Rosselkhoznadzor]). Although cause of death was not determined, photographs showed scarring which indicated that the whale had experienced a previous non-lethal entanglement (WGWAP-7 report). Photographs of a weathered whale carcass (approximately $8 \mathrm{~m}$ ) found on the southeastern shore of Sakhalin in early October 2010 showed rope among the bones, and experts who examined the photographs concluded that entanglement could not be ruled out as a cause of death (WGWAP-16 report). A live WGW photographed off northeastern Sakhalin on 22 August 2013 had rope around its caudal peduncle similar in color and type to that used in the nearby salmon set net fishery (Weller et al. 2014). A rope-related wound on the peduncle appeared relatively fresh. The same whale was seen the next year without the rope and with no evidence of serious injury apparent in photographs (WGWAP-14 report). This incident coincided with the first known deployment of salmon set nets directly in the Piltun feeding area since 1995 when annual research on gray whales in the region began (Weller et al. 2014). In 2014, fishermen reported that a large whale (reportedly $>10 \mathrm{~m}$, species undetermined) was found dead in a salmon trap south of Piltun Lagoon, where gray whales are the most common large whales (WGWAP-14 report). A WGW was photographed in the Piltun area on 12 September 2016 entangled by a long rope with numerous floats, identical to those used in coastal salmon set nets. The whale was not seen and reported again afterwards (WGWAP-16 report). Finally, a gray whale was entangled in a salmon set net in southern Karaginsky Gulf in early July 2017. A video of the event (https://
www.youtube.com/watch?v=9Qv9FYyK8bQ) and communications with the fisherman indicate that the whale was completely disentangled and swam away (A. Burdin pers. comm.).

Bradford et al. (2009) examined photographs of WGWs at Sakhalin and found that 28 of 150 individuals $(18.7 \%)$ had signs of injury from fishing gear at least once. Unfortunately, in this type of analysis the locations where whales encountered the gear and the specific fisheries involved cannot be determined.

\section{Other Asian waters}

Thousands of 'set nets' (alternatively called 'stationary uncovered pond nets') are used all along the coast of Japan. They consist of a long, anchored lead net (up to $1 \mathrm{~km}$ ) that is meant to guide large fish and other marine animals shoreward and into a large anchored enclosure (up to $50 \mathrm{~m} \times 250 \mathrm{~m}$ ) where they usually stay alive for several days or until they are removed by the fishermen. For details see Nédélec \& Prado (1990) and IUCN (2009).

During 2005-2007, 4 gray whales died in set nets of this type along the Pacific coast of Honshu, Japan (Weller et al. 2008, Kato et al. 2013). The first was a young female that was seen repeatedly in Tokyo Bay from mid-April until early May 2005, when it was found dead in a net. In mid-July 2005, a mother and her female calf died in a set net off Enoshima Island, and in January 2007, a young female was entrapped in a set net in Yokahama Bay. Photographs were taken of all 4 whales, but only those from 1 whale were suitable for photo-identification. Comparisons with the WGW photo-identification catalogue revealed that this individual had been photographed and biopsied as a calf off northeastern Sakhalin in July and August 2006 (Weller et al. 2008).

On 5 November 2011, a $13.1 \mathrm{~m}$ female gray whale died from entanglement in a set net in the Taiwan Strait near the mainland coast of China (Wang et al. 2015). Comparisons of photographs of that whale with the eastern and western North Pacific gray whale photo-identification catalogues revealed no matches.

\section{US waters}

IWC (2016) tabulated known entanglements of gray whales in the eastern North Pacific, not including Alaska, for the period 1978-2012. In this 35-year period there were 79 recorded deaths caused by entanglement in fishing gear and 202 injuries (de- 
gree of injury was not specified). The documented bycatch rate (including deaths and injuries) was about 8 whales $\mathrm{yr}^{-1}$ for that region. Carretta et al. (2015) reported on the documented bycatch of gray whales, including serious injuries and mortality (SI/M), along the US west coast, including Alaska, during 2008-2012, where the average annual known fishery-caused SI/M was 4.4 whales $\mathrm{yr}^{-1}$. Incidents, including those that were not judged to cause SI/M, were reported from January to October, in nets (8), pot gear (7), lines/buoys only (9), and trawls (1). While these assessments provide some data on levels of human-caused SI/M and the types of fishing gear associated with such, they represent only a minimum count of impacts because not all, and perhaps only a small proportion, of these incidents are detected and reported (Carretta et al. 2017).

During 2012-2016, a total of 52 entangled gray whales were reported along the US west coast. In the 21 cases where the type of fishing gear was confirmed or suspected, 8 involved nets and 13 involved pot lines. In 11 cases, the gear was identified as originating from the Dungeness crab Cancer magister pot fishery (L. Saez pers. comm.).

\section{Description of fisheries that may entangle or entrap WGWs in the RFE}

The following is a summary of the characteristics of selected RFE fisheries. Additional details are presented in Tables S1-S6 and Figs. S1-S13 in the Supplement at www.int-res.com/articles/suppl/n037 p133_supp.pdf.

\section{Gillnet fisheries}

Two types of marine gillnet fisheries operated in the RFE in 2010-2014, the drift gillnet fishery for Pacific salmon (Oncorhynchus spp. and the bottomset gillnet fishery that principally targets Pacific halibut Hippoglossus stenolepis.

During 2010-2014, the Russian salmon drift gillnet fishery operated over a vast area offshore of eastern and southwestern Kamchatka and the Kuril Islands. Fishermen used synthetic monofilament nets 30$60 \mathrm{~m}$ long and 6-10 m deep with mesh sizes of 60 $80 \mathrm{~mm}$. As many as 100-150 nets were connected in 1 line, and boats sometimes set several lines a day. Soak time varied between 6 and $15 \mathrm{~h}$. Total annual effort when catch was reported averaged 2477 vessel-days (range 2213-2797). A total of 88 Russian vessels participated in the fishery with an average of 54 (range 46-59) vessels fishing annually. The fishing season started in early or mid-May, with fishing activity increasing from May to July, then dropping sharply in August and ending in early to mid-September. Essentially no fishing occurred during October-April. The commercial salmon driftnet fishery has been banned in Russia since 1 January 2016 (Anonymous 2015).

The bottom-set gillnet fishery for demersal fish operated almost entirely in the Okhotsk Sea, with most effort off western Kamchatka and northeastern and southeastern Sakhalin Island. Bottom-set nets are quite similar to driftnets but have heavier lead lines and are held on the bottom with anchors. One anchor has a buoy and line going to the surface. Bottom-set gillnets are used to catch halibut, Atka mackerel Pleurogrammus monopterygius, and thornyheads Sebastolobus spp. Annual effort when catch was reported averaged 1035 vessel-days (range 916-1112). A total of 48 Russian vessels participated in the fishery with an average of 23 (range 16-29) vessels fishing annually. Over $70 \%$ of fishing effort occurred in areas with depths of $500 \mathrm{~m}$ or more, with those vessels targeting halibut and thornyheads. About $20 \%$ of the effort occurred on the shelf at 20-100 m depth and targeted Atka mackerel. Fishing effort steadily increased from January to June and decreased from July to December. In total, $88 \%$ of the fishing effort occurred in April-December.

Longline fisheries

Two types of longline fisheries in the RFE are common in WGW habitat, namely the demersal groundfish longline fishery and the squid vertical longline fishery. The groundfish and squid fisheries are about equal in fishing effort-the combined annual effort for the period 2010-2014 averaged 12198 vessel-days (range 9531-14745). A total of 345 vessels participated in the fisheries during 2010-2014, with an average of 204 (range 163-242) vessels fishing annually.

Target species in the groundfish longline fishery are Pacific cod Gadus macrocephalus, Pacific halibut, Greenland turbot Reinhardtius hippoglossoides, Kamchatka flounder Atheresthes evermanni, thornyheads (Sebastidae), rattails Macrourus spp., rockfish Sebastes spp., Atka mackerel, and eelpouts (Zoarcidae). Many other demersal fish species such as sablefish Anoplopoma fimbria, batoids or rays (Batoidea), gobies (Gobiidae), flatfishes (Pleuronectidae), crabs 
(Decapoda), and cephalopods (Cephalopoda) are caught as non-target species, but their catch volume is very small compared to that of the target species. Six different types of longline gear were used in the RFE in 2010-2014. In general, they use a synthetic main line 1-2 km long with shorter lines with hooks attached via swivels. One longline set has 1000-2000 hooks. Both ends of the set have lines that go from an anchor to a buoy at the surface. One boat usually sets 3 or more longlines. Soak time is $6-24 \mathrm{~h}$.

Along the east coast of Kamchatka, the fishery uses a large portion of the shelf at depths of 100-300 m. Over $92 \%$ of effort was within this depth range, and $54 \%$ was within $100-200 \mathrm{~m}$. Only $5 \%$ of the fishing effort was reported in depths of 20-100 m. A similar distribution of fishing effort was reported in the northern Kuril Islands area, with $81 \%$ of the effort in the shelf break zone $(100-300 \mathrm{~m})$ and half of that effort in the 100-200 m zone. Only $4 \%$ of the effort occurred in 20-100 m and 15\% was in areas deeper than $300 \mathrm{~m}$. Most of the RFE groundfish longline effort in WGW habitat (67\%) occurs in the Okhotsk Sea along the western Kamchatka coast. In that region, only $28 \%$ of the fishing effort was in 100 $300 \mathrm{~m}$ depths and only $5 \%$ of that was in 100-200 m and $<1 \%$ was in $<100 \mathrm{~m}$. The majority of the effort $(71 \%)$ was in waters over $300 \mathrm{~m}$ deep. Demersal longline vessels fished year-round, with the greatest fishing effort in January and February and the least in September and October.

The vertical longline fishery targets Pacific flying squid Todarodes pacificus, and, to a much lesser extent, other squids such as neon flying squid Ommastrephes bartramii. Nearly the entire fishing area is located in the Sea of Japan. Operational depth is 10-100 m. It is a seasonal fishery that occurs in JulyOctober.

\section{Snurrevad fishery}

The snurrevad fishery is one of the most common groundfish fisheries in coastal waters of the RFE, especially along both sides of Kamchatka and the northern Kuril Islands, and in the Primorie region in the northern Sea of Japan. Substantial effort also occurs in the western Kuril Islands, southern Sakhalin Island, and the northern Okhotsk Sea near Magadan. Total annual effort when catch was reported averaged 17927 vessel-days (range 16477-20656). A total of 392 vessels from $20-50 \mathrm{~m}$ in length participated in the fishery during 2010-2014, with an average of 287 (range 260-316) vessels fishing annually.
The snurrevad is a type of seine gear that is deployed while the boat moves in a circle. Deployment starts by putting a buoy with 500-800 m of cable attached in the water as the boat moves forward. After this cable is out, the seine goes in the water and after the seine a second cable of the same length as the first. The boat continues making a circle to the buoy where the operation started. Then the boat pulls both cables and the cables slip along the bottom pushing fish to the middle of the circle and then into the seine.

The snurrevad fishery operates mostly on the continental shelf at 20-200 m depths, where $84 \%$ of the effort occurs. Target species are walleye pollock Gadus chalcogrammus, Pacific cod, and flatfishes. A large variety of other demersal species such as sculpins (Cottidae), Pacific halibut, saffron cod Eleginus gracilis, and herring Clupea harengus are caught as bycatch. The fishery operates year-round, but in summer months the effort is 2-2.5 times higher than in late fall and winter.

\section{Demersal trap and pot fisheries}

A large-scale fishery using demersal traps and pots exists in the RFE. During 2010-2014, fishing effort was spread widely in the Okhotsk Sea and Sea of Japan, with major fishing areas located on the shelf along western Kamchatka, in the northern Okhotsk Sea, along the shelf off the east coast of Sakhalin, and along the Asian mainland shelf in the Sea of Japan. Annual effort when catch was reported averaged 14019 vessel-days (range 11978-15528). A total of 216 Russian vessels participated in the fishery with an average of 139 (range 120-148) vessels fishing annually.

Trap and pot gear is deployed on the bottom by 2 methods. One is to set several dozen traps or pots that are connected to one another with a line $1000 \mathrm{~m}$ or more long that is anchored at each end. Each end of the set has a rope connected to a surface buoy that fishermen use to retrieve the gear. The other method is to set single traps or large pots on the bottom, each of which has a rope that goes to a surface buoy.

These types of gear are used to catch crabs, demersal fish, octopus, shrimp, and whelk. Over $85 \%$ of the fishing effort in the trap and pot fishery is for crabs. The major target species are Alaskan king crab Paralithodes camtschaticus, spiny king crab P. brevipes, blue king crab P. platypus, golden king crab Lithodes aequispinus, triangle tanner crab Chionoecetes angulatus, tanner or bairdi crab C. bairdi, beni-zuwai crab C. japonicus, and snow or opilio crab C. opilio. 
The fishery uses the shelf $(0-200 \mathrm{~m})$ and shelf break (201-500 m), for 47 and $38 \%$ of total effort. It operates year-round but is most active in May-June and September-November, when effort is 3-4 times higher than in the other months.

\section{Coastal salmon set net fishery}

The average annual catch of Pacific salmon in coastal waters of the RFE (not including the offshore drift gillnet fishery) in 2010-2014 was over $400000 \mathrm{t}$ (range 324600-504600 t; Shuntov et al. 2017). Salmon are harvested all along the coast from the Anadyr River in Chukotka to Peter the Great Gulf in the Primorie region, including the Kuril Islands. The most effort occurs along the east and the southern half of the west coast of Kamchatka and the east coast of Sakhalin Island (Fig. 3). All 6 species of Pacific salmon inhabit RFE rivers and surrounding seas, but those of primary commercial value (96$99 \%$ of total catch in 2010-2014) are pink Oncorhynchus gorbuscha, chum O. keta, and sockeye O. nerka (Radchenko 1998, Shuntov et al. 2017). Salmon fish- eries are managed by regional governments, and the annual commercial catch varies greatly depending on the size of runs. During 2011-2015, the commercial catch at Sakhalin fluctuated between 75000 and 220000 t, and at Kamchatka between 132000 and 261000 t. The 2 regions accounted for $76-96 \%$ of the total coastal catch in the RFE (Nagornov et al. 2016, Shpigalskaia et al. 2017, Shuntov et al. 2017).

Three main types of gear are used to catch salmon in coastal waters, lagoons, and rivers: set nets, small seines, and set gillnets. Seines and gillnets are used mostly in rivers and lagoons and should not pose a risk to whales. Set nets are used for most of the salmon harvest in Kamchatka and Sakhalin, where about 700-800 such nets are fished annually (our estimate based on Nagornov et al. 2016).

Of particular concern for WGWs is the set net fishing around Sakhalin Island. The entire coast is a potential salmon fishing ground, and it is divided into small sections assigned by the Sakhalin Government to local private fishing companies for a 20 yr period (Fig. 4A). Once salmon fishing rights for an area are assigned to a company, only that company has the

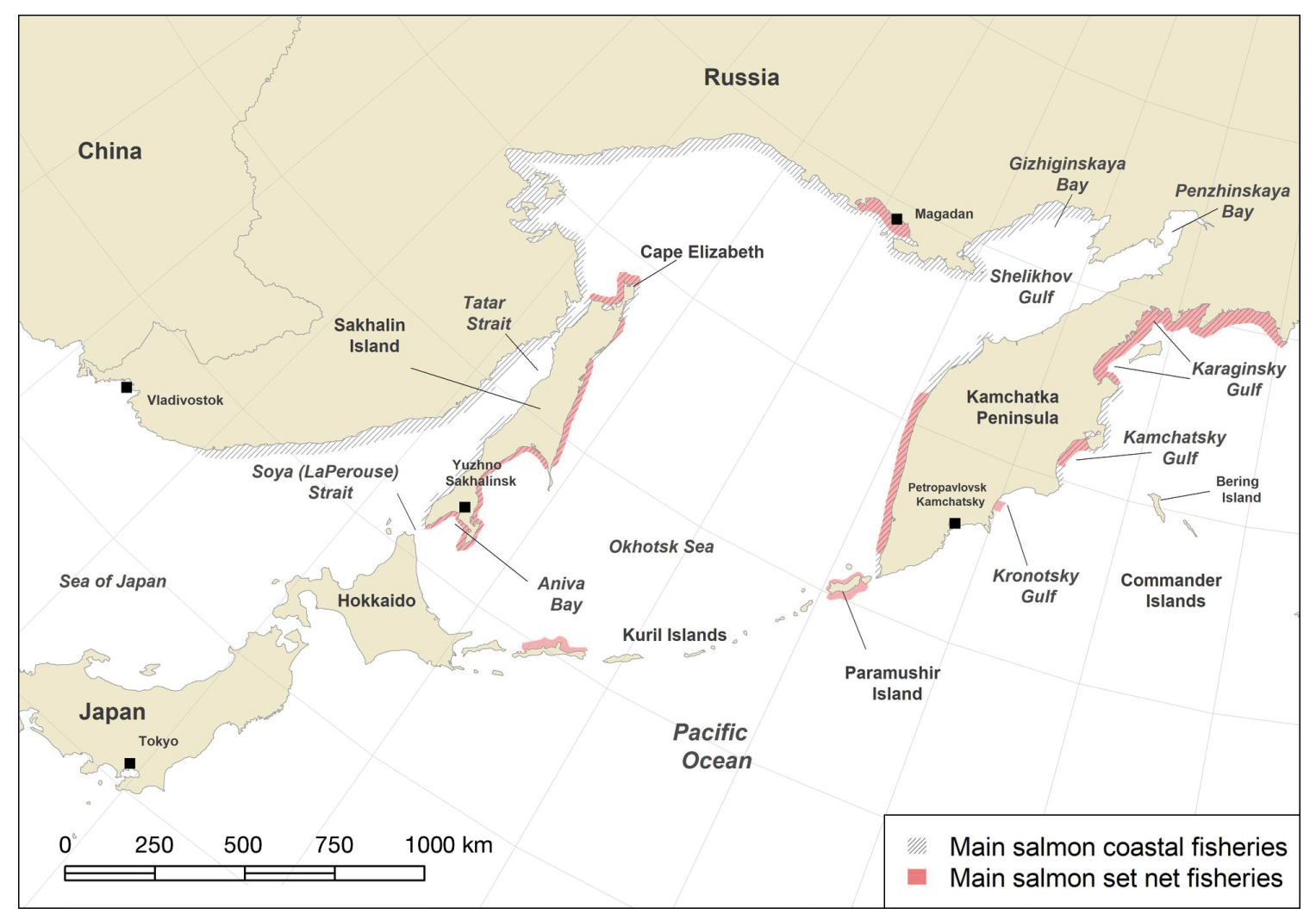

Fig. 3. Distribution of the main coastal salmon fisheries using small seines and set gillnets (gray shading) and the coastal salmon set net fisheries (red shading) in the Russian Far East 


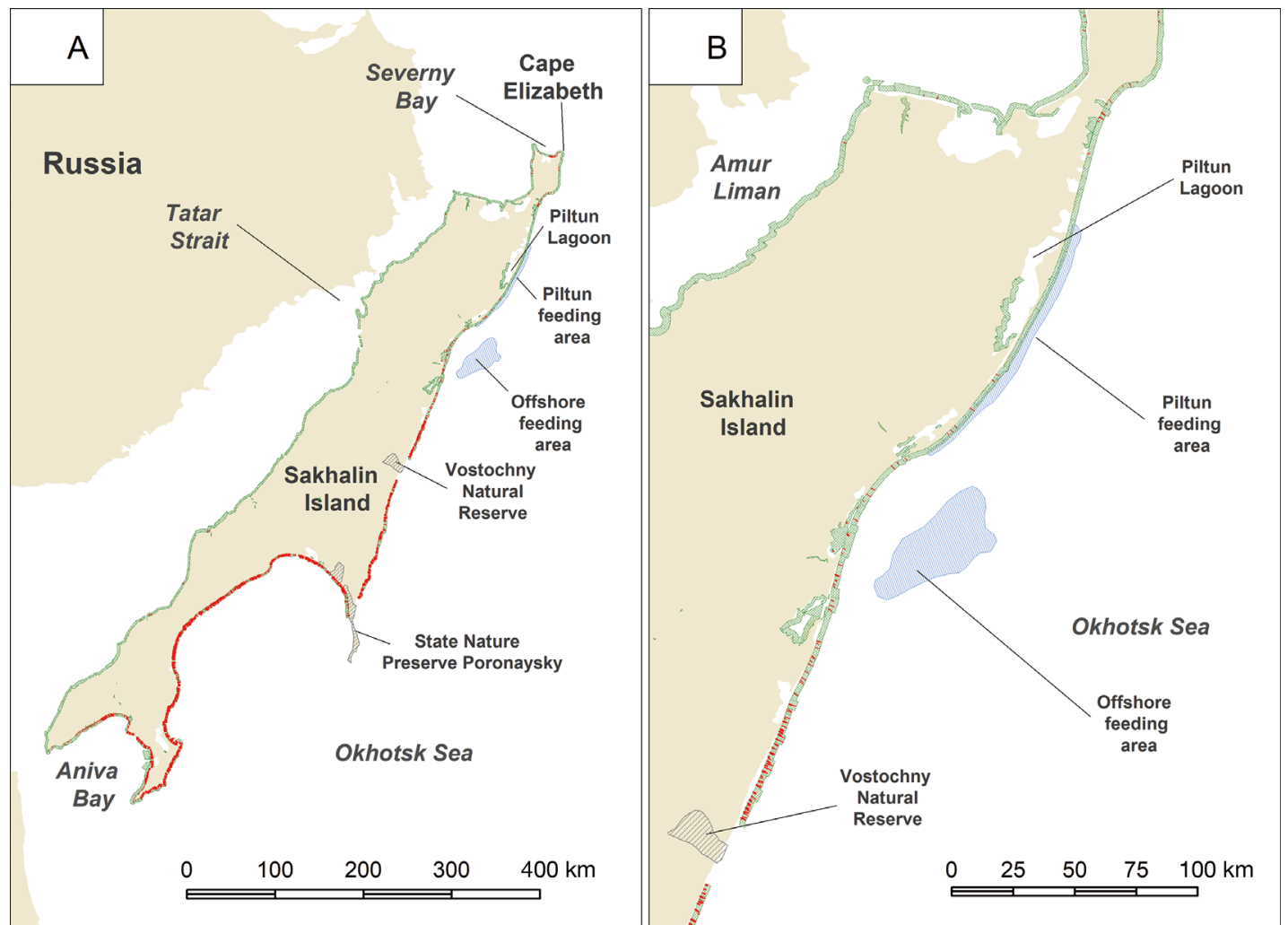

Fig. 4. Locations of coastal salmon set net fishing activity around Sakhalin Island, 2011-2015. (A) All of Sakhalin. (B) Detail of the area that includes the Piltun and offshore feeding grounds of gray whales. Green lines along the coast are salmon fishing parcels that have been allotted to private companies and local communities. Red lines show actual set net locations along the Sakhalin coast in 2001-2015. Note that the near-shore fishing parcels at Piltun overlap substantially with the whale feeding ground (blue area) which extends nearly to the shoreline

right to fish salmon there, and it is responsible for all fishing operations. Several sections can be assigned to 1 company. The net used is a large structure attached to the beach with up to $3 \mathrm{~km}$ of $10 \mathrm{~m}$ high meshed fence-line set perpendicular to the coast (Fig. 5). The fence guides salmon into 1 or more attached floating traps. Many ropes and cables, some extending up to several hundred meters, are used to

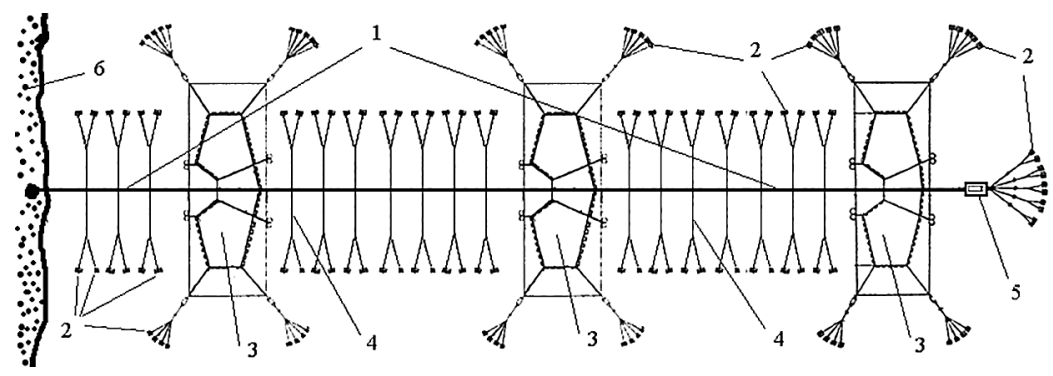

Fig. 5. General layout of a coastal salmon set net like those used on Sakhalin Island (from Datsun et al. 1999). 1: main meshed line that serves as a $2-3 \mathrm{~km}$ long fence; 2: anchors or sand bags; 3 : salmon traps; 4: anchor ropes; 5 : central buoy; 6: coastline anchor the net to the seafloor. This gear is functionally identical to the Japanese set nets discussed earlier.

The commercial salmon fishing season usually starts in early July and lasts until early or midSeptember, but fishing activity on the coast and in coastal waters may actually start in early June and last until mid- or late September. Installation of the set net requires 20-30+ people, small wooden, fiberglass, or metal fishing boats, and barges 6-20 m long. Catch is usually transferred to processing factories on shore, but during years with high salmon runs, large vessels anchor near the set nets to process and freeze the catch. After the salmon fishing season is closed, fishermen remove the set nets. Some ropes or cables that break during the fishing season or in the net removal process may be left at the fishing location with buoys or a few floats attached. This 
gear could be used during the next fishing season or be abandoned.

The Sakhalin Government permits companies to install 550-650 coastal salmon set nets annually. The actual number of installations within permitted parcels is determined by the fishermen, and during 2011-2015, more than 400 set nets were usually set at Sakhalin mostly along the central and southeast coasts (Fig. 4A). Effort was lower along the northeast coast where the WGW summer feeding grounds are located (Fig. 4B), but in 2015, several nets were set very near the entrance of Piltun Lagoon.

SEW monitored the coastal salmon fishery on Sakhalin Island in 2011-2015 using high-resolution satellite imagery to verify compliance with the regulations. Observations included distance between set nets and from mouths of nearest rivers, length of the meshed fence-line attached to the shore, and the fence-line configuration. The SEW study also provided the information on actual set net locations presented in Fig. 4B (D. Lisitsyn \& N. Vorobiev pers. comm.). The study found that, in violation of fishery regulations, the main fence-lines of some set nets extended up to $5.7 \mathrm{~km}$ offshore.

\section{DISCUSSION}

\section{General considerations}

Set nets are known to entrap or entangle, and kill, WGWs off Japan (Weller et al. 2008), and recent observations show that the whales also become entangled in coastal salmon set net gear in the RFE (Weller et al. 2014, WGWAP-17). Similar types of fishing gear entrap other species of large whales in other areas (Song et al. 2010, Benjamins et al. 2012). Heyning \& Lewis (1990) reported that most gray whale entanglements off California were attributable to inshore set gillnets and consisted predominantly of whales 3 yr old or younger. Baird et al. (2002) found that gray whale entanglements off the coast of British Columbia, Canada, occurred in salmon drift gillnet, salmon seine, herring net pen, longline, and trap/pot fisheries.

Even without clear knowledge of when, where, and in what fisheries whales are becoming entangled, it is possible to use GIS analysis to assess the risk of entanglement based on distributions of the whales and of the potentially entangling gear. Saez et al. (2013) conducted such a study of commercial fixed-gear fisheries along the coasts of California, Oregon, and Washington. To do this, they used port- based landings data and depth-defined potential fishing areas to represent commercial fishing effort, along with a model of seasonal gray whale density (DeAngelis et al. 2011), to identify areas and times when entanglement was expected to be more likely. Gray whales were determined to be at greatest risk of entanglement during their annual migration between December and June, and several areas and times of high co-occurrence were identified. The Dungeness crab fishery had the highest cooccurrence scores and thus was judged to be the highest-risk fishery for all whale species considered in the study by Saez et al. (2013) (gray, humpback Megaptera novaeangliae, blue Balaenoptera musculus, fin B. physalus, and sperm whales Physeter macrocephalus).

An analysis similar to that of Saez et al. (2013) would be useful to examine the risk of WGWs becoming entangled in fishing gear in the RFE. This paper presents much of the needed information on characteristics of RFE fisheries, focusing on the types of gear thought to represent the highest risk. However, the information currently available on WGW distribution and movements is insufficient to model seasonal density patterns. The best that can be done at present is to conduct a preliminary and qualitative assessment of risk. We do so below taking into account factors including (1) evidence that the gear type has entangled large whales, described above, (2) fishing effort (see Tables S1-S6), and (3) geographic and temporal overlap between WGWs and fishing activity (see Figs. S1-S13). We also assume that the fishery data analyzed here accurately represent current and near-term future effort in the various fisheries.

\section{Entanglement risk in RFE fisheries}

Most of the historical effort in the RFE commercial salmon driftnet fishery was in the Pacific Ocean far offshore, and effort was concentrated in summer months when most of the gray whales in the western Pacific are feeding near shore. Some WGWs may have encountered salmon driftnets near southern Kamchatka and the northern Kuril Islands during their seasonal movements, and some large whales are known to have been caught and killed in those areas. Drift gillnet fishing for salmon is now banned in Russia and therefore should, in principle, no longer be an issue. However, several fishing boats were stopped and their captains arrested in summer 2016 along the Pacific coast of Kamchatka because 
they were fishing illegally for salmon with driftnets using permits issued for the scientific floating salmon set net fishery. Similar activity was observed along the Pacific side of the northern Kuril Islands in early July 2016 (V. N. Burkanov unpubl. data). Although there is currently a ban on drift gillnets, fishermen are exploring ways to get around the ban, for example by anchoring the net in deep water and calling it a 'set net.'

There are no records of the bottom-set gillnet fishery interacting with WGWs. The fishery overlaps with the known distribution of WGWs in space and time off eastern Sakhalin Island, off southwestern Kamchatka, and north of the northern Kuril Islands. Most fishing occurs well offshore of the known summer and fall feeding areas, but whales may pass through these regions when making seasonal movements. Fishing effort is highest in summer months when whales are relatively abundant at Kamchatka and continues in the late fall and winter when some gray whales from Sakhalin have been tracked moving through this area on their eastward migration. Therefore, the bottom-set gillnet fishery poses some risk to WGWs.

Longline fishing gear has only infrequently been identified as entangling gray whales, but rope and line, some of which may have come from longline gear, are commonly reported on entangled animals. The demersal longline fishery overlaps in space and time with known WGW distribution offshore in the Okhotsk Sea, along eastern and western Kamchatka, and around the northern Kuril Islands. There are no known records of gray whale interactions with longline fisheries in the RFE, but based on year-round fishing, substantial fishing effort, and areas where fishing occurs, there is high likelihood that entanglements occur in some areas. The vertical longline fishery for squid operates in the Sea of Japan during late summer and early fall. The fishery does not overlap with any currently known WGW feeding areas. In the past several decades, gray whales have been occasionally reported in the Sea of Japan but usually not during months when the fishery has operated, and the likelihood of interactions with this fishery is low.

Effort in the snurrevad fishery is the highest of all fisheries that are analyzed in this report, and fishing is conducted year-round. The area of most intense fishing overlaps with the known seasonal distribution of WGWs along the Kamchatka Peninsula and in the northern Kuril Islands. These fishing operations are also quite active along the southern Sakhalin coast and in the southwestern Sea of Japan. Long and loose cables, especially when vessels deploy the gear, may entangle whales. There is an anecdotal report of a large dark whale (possibly a gray whale) entangled in snurrevad gear in the northern Kuril Islands in the late 1980s, and firm documentation (video available at https://www.youtube.com/watch? $\mathrm{v}=0 \mathrm{SP} 5 \mathrm{z} 1 \mathrm{oIsbM}$ ) of a humpback whale entangled in a snurrevad seine near the Kamchatka Peninsula in 2015 (V. N. Burkanov unpubl. data). It is likely that some WGWs become entangled in this fishery, especially in southern Kamchatka and the Kuril Islands.

Trap/pot gear frequently entangles gray whales (and other large whale species), presumably because of the long, loose buoy lines, and lines connecting pots and traps set in strings. Trap and pot fishing is widespread along much of the coastline and on the shelf and shelf break of the Okhotsk Sea and Sea of Japan. It also occurs much less intensively in the Kuril Islands and along eastern Kamchatka. WGWs are likely to encounter trap and pot gear throughout their distribution in the RFE. Much of the fishing effort occurs in April-October when whales are most abundant in the region, and the fishery operates year-round with substantial effort in NovemberDecember when the whales are migrating. Demersal pot and trap fisheries pose a relatively high risk of entangling WGWs.

The coastal salmon set net fishery uses a net fence that extends from shore to $1-3 \mathrm{~km}$ or more offshore. The fishery operates during summer and presents a risk of entanglement/entrapment whenever it occurs in areas that are used by gray whales. This gear is used intensively in 3 major areas of the RFE, i.e. the east coast of Sakhalin, the southern half of Sakhalin, and the west coast of Kamchatka. During summer, more than 100 WGWs, including mother-calf pairs and newly weaned calves, are present and feeding off northeastern Sakhalin. When coastal salmon set nets are placed in areas used by whales, they obstruct movements and result in entanglements or entrapments that lead to injury or death. Many WGWs feed in the vicinity of Piltun Lagoon for 2 mo or more, and the set nets extend completely across and beyond the nearshore feeding area, creating a very high risk of injuring or killing whales. Salmon set net fishing gear also creates a risk to migrating or feeding gray whales elsewhere, especially along the west coast of Kamchatka.

The Okhotsk Sea population of bowhead whales Balaena mysticetus is also listed as Endangered in the IUCN Red List (Cooke et al. 2018). Shpak \& Stimmelmayr (2017) observed 'linear scars at the base of the peduncle consistent with line entanglement' on 
photographs of several bowheads from the western Okhotsk Sea in 2011-2013. Sightings compiled by Shpak \& Paramanov (2018) showed that bowheads in the northwestern Okhotsk Sea spend much of their time in very shallow water where salmon set nets are in place. They also report observations by fishermen that the whales sometimes strike and pass through the nets, and that in 2012 a female bowhead and her calf were entangled in a set net and the female was released but the calf died. In April 2018, the carcass of a subadult bowhead whale was found on the west coast of Sakhalin Island with the flukes missing and severe scarring from line entanglement on the peduncle. An investigation and necropsy concluded that the whale likely drowned in a set net in the Shantar area and drifted to Sakhalin Island where it came ashore (P. van der Wolf pers. comm.).

\section{CONCLUSIONS AND RECOMMENDATIONS}

In this paper, we have begun to identify and characterize, by region, specific fisheries within the RFE that may entangle or entrap gray whales (Table 2). The information shows that entanglement risk in the coastal salmon set net fishery near Piltun Lagoon is very high. This is especially of concern because the nearshore feeding area immediately north and south of the lagoon mouth is used by adult females and their calves at a critical time when the females are recovering condition following pregnancy and lactation and the calves are being weaned. While options (e.g. gear modifications) may exist to reduce this risk, the only way to eliminate it is to stop the setting of salmon set nets in or near the areas being used by the whales. This change can be readily implemented if the Sakhalin Government does not issue permits for salmon set nets in this region, which is a relatively very small portion of the entire salmon fishing extent around the island. Entanglements of WGWs in set nets in other parts of the RFE likely occur, and moni- toring and reporting of such events should be required. Also, the salmon driftnet fishery, which has been shown to entangle and drown large whales as well as other marine mammals and seabirds (Artukhin et al. 2010), should remain closed.

Assessing the risks to WGWs from other openocean fisheries is much more difficult. A major obstacle to identifying the co-occurrence of those fisheries and gray whales is the shortage of information on the seasonal distribution and movements of the whales. Mate et al. (2015) demonstrated that satellite-linked tags can provide such information, and recommendations for additional tagging efforts have been made repeatedly (e.g. Brownell et al. 2010, IWC 2015, WGWAP-12 report). We believe that collecting additional satellite-tag data from WGWs is the most important next step in refining the assessment of entanglement risk from fisheries. Additional research approaches should also be supported, including field surveys (from ships, manned aircraft, drones, and shore), photo-identification, and passive acoustics.

Observations and reports from fishermen represent another useful source of information on fisherywhale interactions. In jurisdictions such as the US, fishermen are required to report marine mammals caught or injured in their operations, and observer programs may be required in places where bycatch is documented to occur. A similar system for reporting and monitoring bycatch is needed in RFE fisheries, particularly the bottom-set gillnet, demersal longline, snurrevad, and trap and pot fisheries.

Additional work is also needed to document fishery interactions throughout the range of gray whales in the western Pacific. Once that information has been collected, it should be combined in a GIS with gray whale distribution and movement data to identify 'hotspots' of risk (e.g. fishery types, regions, and seasons). This should lead to efforts to identify, evaluate, and implement specific strategies to eliminate, or at least mitigate, the entanglement risks — something

Table 2. Preliminary summary of the risk of entanglement or entrapment to gray whales in Russian Far East fisheries

\begin{tabular}{|lcccccc|}
\hline Fishery & $\begin{array}{c}\text { Sea of } \\
\text { Japan }\end{array}$ & $\begin{array}{c}\text { Sakhalin } \\
\text { Island }\end{array}$ & $\begin{array}{c}\text { Okhotsk } \\
\text { Sea offshore }\end{array}$ & $\begin{array}{c}\text { Western } \\
\text { Kamchatka }\end{array}$ & $\begin{array}{c}\text { Kuril } \\
\text { Islands }\end{array}$ & $\begin{array}{c}\text { Eastern } \\
\text { Kamchatka }\end{array}$ \\
\hline Salmon drift gillnet & None & None & None & None & None & None \\
Bottom-set gillnet & None & Some & Some & Some & Some & Some \\
Demersal longline & None & Some & High & High & High & High \\
Squid vertical longline & Low & None & None & None & None & None \\
Snurrevad & Some & Some & None & High & High & High \\
Trap and pot & Some & Some & Some & High & Some \\
Coastal salmon set net & None & Very high & None & High & Some \\
\hline
\end{tabular}


that might best be undertaken regionally, or fishery by fishery.

As a final point, it is clear that for WGWs to recover throughout their historical range, accidental mortality and serious injury in fishing gear must be minimized to the greatest extent possible (IUCN 2009). Authorities, as well as fishermen and fishing companies, in all of the range states need to be made aware of and acknowledge the risks that fisheries represent to these animals.

Acknowledgements. This work was supported by IUCN, and we thank Giulia Carbone, Anete Berzina-Rodrigo, and Jérôme Duramy for their help and encouragement. Project design was facilitated through the WGWAP. We thank our colleagues in WGWAP, SEIC, and SEW for providing valuable information and assistance, and the Centre of Fishery Monitoring and Communications for providing the depersonalized DCR data set. Captain Yury Leshtaev of the fishing vessel 'MRC-150-092' provided information about the entanglement event in Karaginsky Gulf and Peter van der Wolf provided unpublished observations of a stranded bowhead whale. We also thank Mike Donaghy, Olga Shpak, Alexander Burdin, David Mattila, Kathy Frost, and 3 anonymous reviewers for helpful comments on earlier versions of this manuscript.

\section{LITERATURE CITED}

Anonymous (2015) Federal'nyy zakon ot 29.06.2015 № 208FZ 'O vnesenii izmeneniy v Federal'nyy zakon 'O rybolovstve i sokhranenii vodnykh biologicheskikh resursov' [Federal Law on 29/6/2015 \# 208-FZ 'On Amendments to the Federal Law on fishing and preservation of aquatic biological resources'] (in Russian)

Artukhin YB, Burkanov VN, Nikulin VS (2010) Priloy morskikh ptits i mlekopitayushchikh na drifternom promysle lososey $\mathrm{v}$ severo-zapadnoy chasti Tikhogo okeana [Accidental by-catch of marine birds and mammals in the salmon gillnet fishery in the northwestern Pacific Ocean]. Skorost' Tsveta, Moscow (in Russian)

Baird RW, Stacey PJ, Duffus DA, Langelier KM (2002) An evaluation of gray whale (Eschrichtius robustus) mortality incidental to fishing operations in British Columbia, Canada. J Cetacean Res Manag 4:289-296

Becker RA, Wilks AR, Brownrigg R, Minka TP (2013) maps: Draw Geographical Maps. R package version 2.3-6. http://CRAN.R-project.org/package=maps

Benjamins S, Ledwell W, Huntington J, Davidson AR (2012) Assessing changes in numbers and distribution of large whale entanglements in Newfoundland and Labrador, Canada. Mar Mamm Sci 28:579-601

Bowen SL (1974) Probable extinction of the Korean stock of the gray whale (Eschrichtius robustus). J Mammal 55: 208-209

Bradford AL, Weller DW, Ivashchenko YV, Burdin AM, Brownell RL Jr (2009) Anthropogenic scarring of western gray whales (Eschrichtius robustus). Mar Mamm Sci 25: 161-175

*Badford AL, Ivashchenko YV, Kirichenko VY, Burdin, AM (2010) Review of cetacean distribution and occurrence off the western coast of Kamchatka, eastern Okhotsk Sea. Paper SC/62/BRG3 presented to the Scientific Committee of the International Whaling Commission. https:// iwc.int/document_1444 (accessed 12 August 2018)

Brownell RL, Chun C (1977) Probable existence of the Korean stock of the gray whale (Eschrichtius robustus). J Mammal 58:237-239

Brownell RL, Donovan GP, Kato H, Larsen F and others (2010) Draft conservation plan for western North Pacific gray whales (Eschrichtius robustus). Western Gray Whale Advisory Panel, IUCN, Gland. www.iucn.org/ sites/dev/files/content/documents/wgw_conservation plan.pdf

Burkanov VN, Nikulin VS (2001) Otsenka sluchaynoy gibeli morskikh mlekopitayushchikh pri drifternom promysle lososya yaponskimi sudami v ekonomicheskoy zone Rossii v 1993-1999 gg [Evaluation of accidental death of marine mammals in the Japanese salmon gillnet fishery in the economic zone of Russia in 1993-1999]. In: Popov LA (ed) The results of studies of marine mammals of the Far East in 1991-2000. Materials for the XVI Meeting of the Working Group on the draft 02.05-61 'Marine mammals' of the Russian-American agreement on cooperation in the field of environmental protection. VNIRO, Moscow, p 222-230

Burkanov VN, Vertyankin VV, Nikulin VS, Testin AI (2007) Vidovoy sostav prilova morskikh mlekopitayushchikh na rossiyskom drifternom love lososey v Kamchatskom regione, 1996-2005 gg [The species composition of bycatch of marine mammals in the Russian salmon gillnet fishery in Kamchatka 1996-2005]. Conservation of biodiversity of Kamchatka and adjacent seas: Materials of the VIII International scientific conference devoted to the 275th anniversary since the beginning of the Second Kamchatka Expedition (1732-1733). Kamchatpress, Petropavlovsk-Kamchatsky, p 201-204

Carretta JV, Oleson EM, Weller DW, Lang AR and others (2015) U.S. Pacific Marine Mammal Stock Assessments: 2014. NOAA Tech Memo NMFS-SWFSC-549. US Department of Commerce, NOAA, La Jolla, CA

Carretta JV, Muto MM, Greenman J, Wilkinson K, Lawson D, Viezbicke J, Jannot J (2017) Sources of human-related injury and mortality for U.S. Pacific west coast marine mammal stock assessments, 2011-2015. NOAA Tech Memo NMFS-SWFSC-579. US Department of Commerce, NOAA, La Jolla, CA

Cooke JG, Brownell RL Jr, Shpak OV (2018) Balaena mysticetus (Okhotsk Sea subpopulation). The IUCN Red List of Threatened Species 2018: e.T2469A50345920. www. iucnredlist.org/details/2467/0 (accessed 6 August 2018)

Datsun VM, Miziurkin M, Novikov NP, Rakov VA, Teliatnik OV (1999) Guide to the coastal fishery: biology, fishing, and processing. Dalrybvtuz, Vladivostok (in Russian)

DeAngelis M, Saez L, MacNeil J, Mate B, Moore T, Weller D, Perryman W (2011) Spatio-temporal modeling of the eastern Pacific gray whale (Eschrichtius robustus) migration through California, Oregon, and Washington. 19th Biennial Conference on the Biology of Marine Mammals, 26 November-2 December 2011, Tampa, FL

*Demchenko NL, Chapman JW, Durkina VB, Fadeev VI (2016) Life history and production of the western gray whale's prey, Ampelisca eschrichtii Krøyer, 1842 (Amphipoda, Ampeliscidae). PLOS ONE 11:e0147304

Filatova OA, Shpak OV, Paramonoa AY, Glazov DM, Grachev AI, Meschersky IG (2016) Cetacean encounters 
in the coastal waters of the northern Okhotsk Sea in summer 2016. Marine Mammals of the Holarctic IX International Conference October/November Astrakhan, Russia

GEBCO (2014) GEBCO 30 arc-second global grid of elevations. https://www.gebco.net/data_and_products/gridded _bathymetry_data/gebco_30_second_grid/ (accessed 2 April 2018)

Gilman E, Brothers N, McPherson GR, Dalzell P (2006) A review of cetacean interactions with longline gear. J Cetacean Res Manag 8:215-223

Henderson DA (1984) Nineteenth century gray whaling: grounds, catches and kills, practices and depletion of the whale population. In: Jones ML, Swartz SL, Leatherwood $\mathrm{S}$ (eds) The gray whale Eschrichtius robustus. Academic Press, Orlando, FL, p 159-186

Henderson D (1990) Gray whales and whalers on the China coast in 1869. Whalewatcher 14:14-16

Heyning JE, Lewis TD (1990) Entanglements of baleen whales in fishing gear off southern California. Rep Int Whal Comm 40:427-431

IUCN (2009) Western gray whales: status, threats and the potential for recovery. Report of the Western Gray Whales Rangewide Workshop, 21-24 September 2008, Tokyo, Japan. https://www.iucn.org/sites/dev/files/tokyo _workshop_report.pdf

IWC (International Whaling Commission) (2004) Report of the workshop on the western gray whale: research and monitoring needs. J Cetacean Res Manag 6(Suppl): 487-500

IWC (2006) Report of the Scientific Committee. J Cetacean Res Manag 8(Suppl):1-77

IWC (2015) Report of the workshop on the rangewide review of the population structure and status of North Pacific gray whales, 8-11 April 2014, La Jolla, CA, USA. J Cetacean Res Manag 16(Suppl):487-528

IWC (2016) Report of the 2nd workshop on the rangewide review of the population structure and status of North Pacific gray whales. 1-3 April 2015, La Jolla, CA, USA. J Cetacean Res Manag 17(Suppl):565-582

Kato H, Kasuya T (2002) Some analyses on the modern whaling catch history of the western North Pacific stock of gray whales (Eschrichtius robustus), with special reference to the Ulsan whaling ground. J Cetacean Res Manag 4:277-282

Kato H, Miyashita T, Kishiro T, Kanda N and others (2013) Status report of conservation and researches on the western North Pacific gray whales in Japan, May 2012-April 2013. Paper SC/65a/BRG20 presented to the Scientific Committee of the International Whaling Commission. https://archive.iwc.int/pages/search.php? search $=$ !collection $138 \& b c \_$from $=$themes (accessed 10 November 2017)

Kornev SI (1994) A note on the death of a right whale (Eubalaena glacialis) off Cape Lopatka (Kamchatka). In: Perrin WF, Donovan GP, Barlow J (eds) Gillnets and cetaceans. Rep Int Whal Comm Spec Issue 15:443-444

KLang AR, Weller DW, LeDuc R, Burdin AM and others (2011) Genetic analysis of stock structure and movements of gray whales in the eastern and western North Pacific. Paper SC/63/BRG10 presented to the Scientific Committee of the International Whaling Commission. https:// iwc.int/private/downloads/U-2q2nigzCD42UP0633uZw/ SC-63-BRG10.pdf (accessed 2 November 2017)

Mate BR, Ilyashenko VY, Bradford AL, Vertyankin VV, Tsidulko GA, Rozhnov VV, Irvine LM (2015) Critically endangered western gray whales migrate to the eastern North Pacific. Biol Lett 11:20150071

Meÿer MA, Best PB, Anderson-Reade MD, Cliff G, Dudley SFJ, Kirkman SP (2011) Trends and interventions in large whale entanglement along the South African coast. Afr J Mar Sci 33:429-439

Nagornov AA, Kovalenko MN, Adamov AA (2016) The current state of trap-net fishing of Pacific salmon in Kamchatka. Research on the aquatic biological resources of the Kamchatka and northwest part of the Pacific Ocean. Collection of Scientific Papers 40:32-41 (in Russian with English Abstract)

Nédélec C, Prado J (1990) Definition and classification of fishing gear categories. FAO Tech Pap 222, Revision 1. FAO, Rome

Nikulin VS, Burkanov VN (2001) Prilov morskikh mlekopitayushchikh na yaponskom promysle $\mathrm{v}$ rossiyskoy IEZ (The by-catch of marine mammals in the Japanese fishing in the Russian EEZ). Rybnoe khozyaystvo 5:32-33 (in Russian)

R Core Team (2016) R: a language and environment for statistical computing. R Foundation for Statistical Computing, Vienna

Radchenko VL (1998) Historical trends of fisheries and stock condition of Pacific salmon in Russia. North Pac Anadromous Fish Comm Bull 1:28-37

Reeves RR, Brownell RL Jr, Burdin A, Cooke JG and others (2005) Report of the Independent Scientific Review Panel on the impacts of Sakhalin II Phase 2 on western North Pacific gray whales and related biodiversity. IUCN, Gland. https://www.iucn.org/sites/dev/files/isrp_report_ with_covers_high_res.pdf

Reeves RR, Smith TD, Josephson EA (2008) Observations of western gray whales by ship-based whalers in the 19th century. J Cetacean Res Manag 10:247-256

Reeves RR, McClellan K, Werner TB (2013) Marine mammal bycatch in gillnet and other entangling net fisheries, 1990 to 2011. Endang Species Res 20:71-97

Reilly S, Bannister JL, Best PB, Brown M and others (2008) Eschrichtius robustus (western subpopulation). The IUCN Red List of Threatened Species 2008: e.T8099A12885692. http://dx.doi.org/10.2305/IUCN.UK.2008.RLTS.T8099A12 885692.en (accessed 10 Aug 2018)

Saez L, Lawson D, DeAngelis M, Petras E, Wilkin S, Fahy C (2013) Understanding the co-occurrence of large whales and commercial fixed gear fisheries off the west coast of the United States. NOAA Tech Memo NMFS-SWR-044. US Department of Commerce, NOAA, Seattle, WA

SEIC (Sakhalin Energy Investment Company) (2011) Summary of joint Okhotsk-Korean gray whale monitoring program findings, Sakhalin, Russian Federation, 20022010. Document 0000-5-90-04-T-0366-00-E. Sakhalin Energy Investment Company, Yuzhno Sakhalinsk. www. sakhalinenergy.ru/media/library/eng/Environmental/ GrayWhales/2.13SummaryoftheJointOkhotsk-Korean GrayWhaleEng.pdf (accessed 15 November 2017)

Shpak OV, Stimmelmayr R (2017) Preliminary image analysis of acute and chronic injuries, parasites, and skin conditions in the Okhotsk bowhead whale (Balaena mysticetus) stock in the western Okhotsk Sea. Rep Int Whal Comm Sci Comm SC/67a/E1. www. iwcoffice.org

Shpak OV, Paramonov AYu (2018) The bowhead whale, Balaena mysticetus Linnaeus, 1758, in the Western Sea of 
Okhotsk (2009-2016): distribution pattern, behavior, and threats. Rus J Mar Biol 44(3):210-218.

Shpigalskaia NI, Bugaev AV, Shevliakov EA, Kovalenko MN (2017) Kamchatka Pacific salmon: fishery and science. Presentation at the scientific conference Aquatic biological resources of Russia: modern state, monitoring and management, Petropavlovsk-Kamchatsky, 3-6 October 2017 (in Russian). www.kamniro.ru/presscenter/ statin/tihookeanskie_lososi_kamchatki_rybnoe_hozyajstvo_ i_nauka (accessed 10 November 2017)

Shuntov VP, Temnykh OS, Ivanov O (2017) On the stability of stereotypes in conceptions on marine ecology of Pacific salmon (Oncorhynchus spp.). Izvestiya TINRO 188:3-36 (in Russian with English Abstract)

Song KJ, Kim ZG, Zhang CI, Kim YH (2010) Fishing gears involved in entanglements of minke whales (Balaenoptera acutorostrata) in the East Sea of Korea. Mar Mamm Sci 26:282-295

Tyurneva OY, Yakovlev YM, Vertyankin VV, Selin NI (2010) The peculiarities of foraging migrations of the KoreanOkhotsk gray whale (Eschrichtius robustus) population in Russian waters of the far eastern seas. Russ J Mar Biol 36:117-124

Tyurneva OY, Yakovlev YM, Vertyankin VV, van der Wolf P, Scott MJ (2018) Long-term photo-identification studies of gray whales (Eschrichtius robustus) offshore northeast Sakhalin Island, Russia, 2002-2017. Paper SC/67B/ASI/04 presented to the Scientific Committee of the International Whaling Commission. https:// archive.iwc.int/pages/themes.php?lastlevelchange $=3 \&$ theme $1=$ Scientific + Committee\&theme $2=$ Meetings

Vertyankin VV, Nikulin VS, Bednykh AM, Kononov AP (2004) Nablyudeniya za serymi kitami (Eschrichtius robustus) yugo-vostoka Kamchatki (Observations of gray whales [Eschrichtius robustus] of south-east of Kamchatka). In: Bel'kovich VM (ed) Marine mammals of the Holarctic: collection of scientific papers based on the third international conference. Marine Mammal Council, Koktebel, p 126-128

Editorial responsibility: Simon Goldsworthy, West Beach, South Australia, Australia
Wang X, Min X, Fuxing W, Weller DW, Xing M, Lang AR, Qian Z (2015) Insights from a gray whale (Eschrichtius robustus) bycaught in the Taiwan Strait off China in 2011. Aquat Mamm 41:327-332

Weller DW, Würsig B, Bradford AL, Burdin AM, Blokhin SA, Minakuchi H, Brownell RL Jr (1999) Gray whales (Eschrichtius robustus) off Sakhalin Island, Russia: seasonal and annual patterns of occurrence. Mar Mamm Sci 15:1208-1227

Weller DW, Burdin AM, Würsig B, Taylor BL, Brownell RL Jr (2002) The western gray whale: a review of past exploitation, current status and potential threats. J Cetacean Res Manag 4:7-12

Weller DW, Bradford AL, Kato H, Bando T, Ohtani S, Burdin AM, Brownell RL Jr (2008) A photographic match of a western gray whale between Sakhalin Island, Russia, and Honshu, Japan: the first link between the feeding ground and a migratory corridor. J Cetacean Res Manag 10:89-91

Weller DW, Klimek A, Bradford AL, Calambokidis J and others (2012) Movements of gray whales between the western and eastern North Pacific. Endang Species Res 18:193-199

Weller DW, Burdin AM, Brownell RL Jr (2013) A gray area: on the matter of gray whales in the western North Pacific. Whalewatcher 42(1):29-33

Weller DW, Sychenko OA, Burdin AM, Brownell RL Jr (2014) On the risks of salmon fishing trap-nets to gray whales summering off Sakhalin Island, Russia. Paper SC/65b/BRG16 presented to the Scientific Committee of the International Whaling Commission. https://archive. iwc.int/pages/search.php?search=!collection165\&bc_from $=$ themes (accessed 2 November 2017)

Werner TB, Northridge S, Press KM, Young N (2015) Mitigating bycatch and depredation of marine mammals in longline fisheries. ICES J Mar Sci 72:1576-1586

Yablokov AV, Bogoslovskaya LS (1984) A review of Russian research on the biology and commercial whaling of the gray whale. In: Jones ML, Swartz SL, Leatherwood S (eds) The gray whale Eschrichtius robustus. Academic Press, Orlando, FL, p 465-485

Submitted: January 2, 2018; Accepted: June 28, 2018

Proofs received from author(s): August 28, 2018 